\title{
OPTIMALISASI PERAN IBU DALAM DALAM PENGENDALIAN FAKTOR RISIKO MASALAH GIZI BALITA DI DUSUN GUMULAN, CATURHARJO, BANTUL
}

\section{OPTIMIZING THE ROLE OF WOMEN IN CONTROLING RISK FACTORS OF NUTRITIONAL PROBLEMS OF CHILDREN IN DUSUN GUMULAN, CATURHARJO, BANTUL}

\author{
Septian Emma Dwi Jatmika ${ }^{\# 1}$, Cita Eri Ayuningtyas *2 \\ \#Program Studi Kesehatan Masyaraka, Universitas Ahmad Dahlan, Jl. Prof. Dr. Seopomo, S.H., Janturan, \\ Warungboto, Umbulharjo, Yogyakarta \\ 1septianemma@ikm.uad.ac.id \\ * Program Studi Bisnis Jasa Makanan, Universitas Ahmad Dahlan, Jl. Prof. Dr. Seopomo, S.H., Janturan, \\ Warungboto, Umbulharjo, Yogyakarta \\ ${ }^{2}$ cita.er@culinary.uad.ac.id
}

Abstrak

Faktor risiko masalah gizi balita yang ditemukan di Dusun Gumulan meliputi kurangnya pengetahuan Ibu tentang pemberian MP ASI sesuai standar World Health Organization (WHO); kurangnya pemanfaatan bahan pangan lokal berkualitas untuk MP-ASI; banyaknya pemberian MP-ASI instan oleh Ibu pada balita; pemberian MP-ASI yang kurang sesuai dengan durasi, frekuensi, tekstur dan variasi sesuai tahapan usia dan kurangnya perhatian orangtua terkait tumbuh kembang balita. Namun disisi lain, Dusun Gumulan memiliki potensi sumber daya manusia (Kader Posyandu) dan sumber daya alam (daerah pertanian) yang dapat dioptimalkan untuk mengatasi masalah tersebut. Dengan demikian perlu adanya program pemberdayaan yang bertujuan untuk meningkatkan pengetahuan dan keterampilan masyarakat dengan mengoptimalkan Peran IbuMetode yang diterapkan adalah pelatihan dan pendampingan pembuatan MP ASI serta evaluasi pelaksanaan . Kelompok sasaran adalah Kader Posyandu dan Ibu Ibu PKK Dusun Gumulan Hasil program pemberdayaan cukup bagus dimana terdapat peningkatan pengetahuan warga setelah diberikan pelatihan pembuatan MP ASI pada warga. Sedangkan hasil penilaian keterampilan warga melalui lomba kreasi aneka olahan MP ASI menunjukkan bahwa secara keseluruhan warga telah mempu membuat olahan MP ASI dengan baik.Dengan demikian, dapat disimpulkan bahwa warga dapat memahami dengan baik materi yang disampaikan dalam pelatihan. Warga berharap ada kegiatan serupa yang dilakukan secara berkelanjutan. .

Kata Kunci: Peran Ibu, Gizi Balita, MP-ASI, Pelatihan,Pendampingan

\section{Abstract}

Risk factors for nutritional problems found in Gumulan Hamlet include the mother's lack of knowledge about complementary feeding according to World Health Organization (WHO) standards; lack of use of quality local food ingredients for complementary foods; the number of instant complementary foods provided by mothers to toddlers; provision of complementary breastfeeding that is not in accordance with the duration, frequency, texture and variation according to age stages and the lack of parental attention related to toddler growth and development. But on the other hand, Gumulan Hamlet has the potential for human resources (Posyandu cadres) and natural resources (agricultural areas) that can be optimized to overcome these problems. Thus, it is necessary to have an empowerment program that aims to increase the knowledge and skills of the community by optimizing the Role of Mother. The methods applied are training and assistance in making MP ASI and evaluation of implementation. The target groups were Posyandu cadres and Ibu PKK Dusun Gumulan. The results of the empowerment program are quite good, seen from the results of the evaluation of the implementation process based on the level of understanding of the citizens about the process of making MP ASI. There is an increase in the knowledge of the residents after being given training on making MP ASI for residents. Meanwhile, the results of the assessment of citizen skills through various creative competitions for MP ASI preparations show that overall residents have been able to make MP ASI preparations well. Thus, it can be concluded that residents can understand well the material presented in the training. Residents hope that similar activities will be carried out in a sustainable manner.

Keywords: Mother's Role, Toddler Nutrition, MP-ASI, Training, Mentorin 


\section{PENDAHULUAN}

Masalah gizi khususnya stunting pada balita sudah menjadi perhatian tidak hanya di tingkat nasional tetapi juga tingkat global. Beberapa program dan kegiatan nasional telah dilakukan untuk mengatasi masalah tersebut. Seiring dengan masalah tersebut, maka Negara dengan prevalensi masalah gizi cukup tinggi membentuk gerakan perbaikan gizi tingkat global yang disebut Scaling Up Nutrition (SUN) dan di Indonesia disebut dengan Gerakan 1000 Hari Pertama Kehidupan ${ }^{1}$.

Ibu memiliki peranan yang besar dalam peningkatan status gizi anggota keluarga. Hal ini dikarenakan Ibu sebagai pembina pertama dan utama terhadap pendidikan dan kesehatan anak, dan pengelola atau penyelenggara makanan dalam keluarga. Oleh karena itu perlu adanya pembinaan di level individu untuk meningkatkan pengetahuan dan kesadaran pangan dan gizi².

Meningkatnya pengetahuan dan kesadaran Ibu akan pangan dan gizi, keterampilan mengelola pangan dan konsumsi gizi seimbang serta sanitasi lingkungan dapat meningkatkan gizi dan mencegah penyakit infeksi yang sering diderita anak. Melalui program pengabdian dan pemberdayaan masyarakat di Dusun Gumulan ini dapat mencapai target yaitu meningkatnya ketrampilan warga dalam mengoptimalkan kearifan lokal yang ada untuk pembuatan MP ASI. Harapannya terdapat perubahan pengetahuan, sikap dan perilaku hidup bersih sehat. Dengan demikian solusi yang ditawarkan dan luaran yang ditargetkan untuk permasalahan tersebut dalam jangka panjang diharapkan dapat meningkatkan status kesehatan balita di Dusun Gumulan, Caturharjo, Pandak, Bantul terutama status gizi Balita.

\section{TARGET DAN LUARAN}

Sasaran pengabdian masyarakat ini adalah Ibu-Ibu anggota Posyandu SAKURA yang memiliki balita. Luaran yang didapatkan adalah meningkatnya pengetahuan dan keterampilan para Ibu dan kader posyandu, diharapkan dapat meningkatkan status kesehatan balita di Dusun Gumulan, Caturharjo, Pandak, Bantul terutama status gizi Balita.

\section{METODE PELAKSANAAN}

Metode yang dilakukan adalah pelatihan dan pendampingan serta evaluasi yang diberikan kepada kader Posyandu Sakura (kelompok mitra) dan Ibu
Ibu PKK Dusun Gumulan. Masyarakat dilibatkan secara aktif dalam pelatihan ini sehingga pengetahuan dan keterampilan para Ibu dan kader posyandu yang baik, sehingga dapat mendukung keberhasilan program. Program pelatihan dan pendampingan yang ditawarkan adalah pelatihan dan pendampingan pembuatan MP ASI menggunakan bahan pangan lokal.

\section{HASIL DAN PEMBAHASAN}

Pelatihan pembuatan MP ASI dilakukan oleh tim Sanggar ASI . Sasaran utama adalah kader dan Ibu Ibu PKK Dusun Gumulan yang berjumlag 27 orang. Materi yang diberikan adalah tentang pemahaman dasar MP ASI, Menyusun Menu MP ASI sesuai Pedoman Gizi Seimbang, Hypnoeating dan praktik pembuatan MPASI berdasarkan WHO menggunakan bahan pangan lokal berkualitas. Pelatihan diberikan tanggal 23 dan 25 April 2019. Dalam praktik pembuatan MP ASI, alat dan bahan difasilitasi oleh tim pengusung berupa alat memasak, aneka tepung, aneka bumbu dapur dan aneka sayur \& buah. Peralatan masak yang dapakai adalah peralatan yang bersifat umum dan sederhana sehingga diasumsikan dimiliki oleh semua keluarga. Peserta sangan antusias mengikuti kegiatan karena metode pelatihan dikemas dengan cara yang menarik sehingga peserta aktif mengikuti kegiatan. Peserta diminta untuk mereview materi menggunakan metode permainan. Di hari kedua pelatihan, peserta melakukan demonstrasi pembuatan MP ASI sesuai dengan panduan WHO.
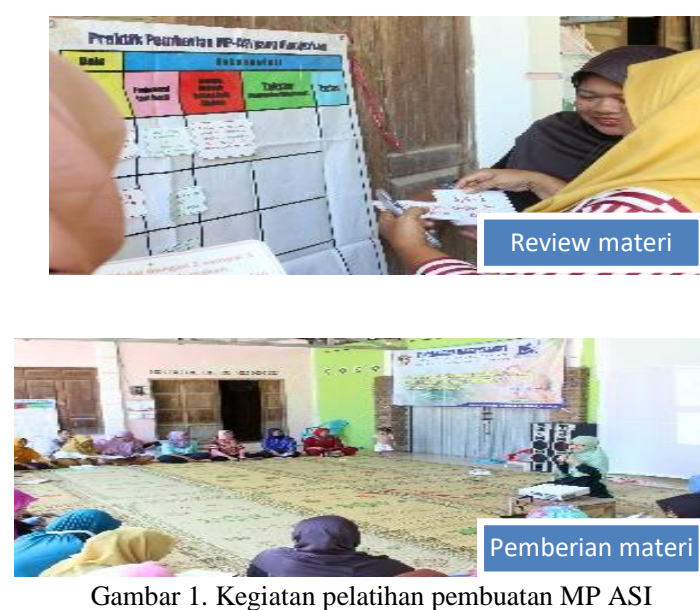

Pendampingan pembuatan MP ASI dilakukan oleh tim pengusung pada tanggal 23 Juli 2019. Pendampingan dilakukan sebagai persiapan lomba dengan memfasilitasi dan mendampingi peserta dalam pembuatan aneka olahan MP-ASI menggunakan bahan pangan lokal. Lomba kreasi aneka olahan MP ASI diikuti oleh seluruh peserta yang terbagi menjadi enam kelompok. Lomba diadakan untuk mengevaluasi hasil 
pelatihan sekaligus memberikan apresiasi kepada peserta pelatihan.

Berdasarkan evaluasi didapatkan hasil bahwa tingkat pengetahuan warga yang mengalami kenaikan setelah dilakukan penyuluhan yaitu sebanyak 20 orang. Namun ada terdapat satu orang yang justru mengalami penurunan. Dengan demikian dapat disimpulkan bahwa pemberian pelatihan pembuatan MP ASI mempunyai pengaruh yang signifikan terhadap peningkatan tingkat pengetahuan ibu tentang pembuatan MP ASI sehingga tujuan dari pelatihan ini telah tercapai. Sedangkan untuk mengevaluasi kemampuan ketrampilannya dengan melalukan kegiatan lomba kreasi aneka olahan MP ASI. Evaluasi hasil dilakukan diakhir sesi kegiatan. Evaluasi hasil yang kami lakukan dengan mengadakan lomba kreasi aneka olahan MP ASI. Hal ini bertujuan untuk menilai ketrampilan para peserta pelatihan. Adapaun kriteria penilaian lomba meliputi variasi bahan dari sumber $4 *$ (keberagaman kandungan gizi), amsakan 3 kelompok umur (tekstur), kombinasi bahan makanan, penyajian mkanan yang sudah masak (penampilan), hygiene sanitias, tingkat ketangan, cita rasa (usia $\geq 12$ bulan) dan alokasi pengunaan subsidi dana. Agenda ini dilakukan sebagai tolak ukur keberhasilan penyerapan materi oleh peserta pelatihan. Perolehan juara didapatkan oleh Kelompok 6 sebagai juara I, Kelompok 2 sebagai juara II, Kelompok 1 sebagai juara III, Kelompok 5 sebagai juara Harapan I, Kelompok 3 sebagai juara Harapan II dan Kelompok 4 sebagai juara Harapan III. Pemenang lomba mendapat hadiah berupa peralatan memasak. Berikut adalah dokumentasi lomba kreasi aneka olahan MP ASI.
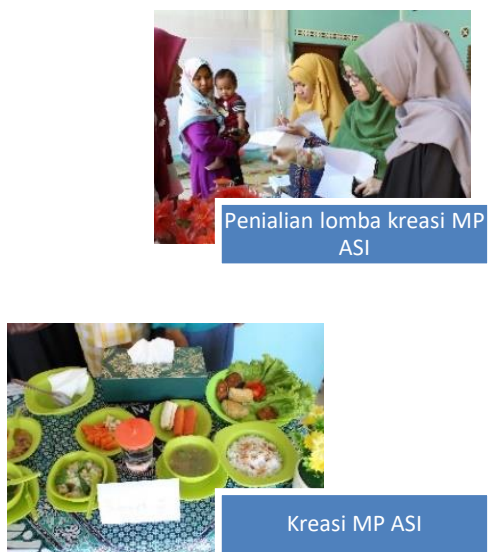

Gambar 2. Lomba kreasi olahan MP ASI
Berikut adalah hasil evaluasi kegiatan pengadian.

A. Pengetahuan awal tentang MP ASI

Kegiatan penyuluhan ini dilakukan di rumah Pak Dukuh Dusun Gumulan dengan materi pengenalan awal makanan pendamping asi (MP-ASI) pada anak. Penyampaian materi ini penting dilakukan agar masyarakat dapat memahami informasi mengenai MPASI. Untuk mengetahui tingkat pengetahuan masyarakat tentang MP-ASI sebelum dilakukan penyuluhan diberikan kuesioner yang berisi 10 Pertanyaan tentang pengenalan MP-ASI.

Berikut adalah pertanyan tentang pengengetahuan awal mengenai MP-ASI :

1) Makanan pendamping ASI mulai diberikan usia 4 bulan

2) Salah satu fungsi zat besi adalah untuk meningkatkan daya tahan tubuh

3) Tekstur MP ASI untuk anak usia 6 bulan -6 bulan 2 minggu adalah bubur kental

4) Tekstur MP ASI untuk anak usia $\geq 12$ bulan adalah cincang halus

5) Pemberian makan utama pada anak usia 9 bulan 11 bulan 29 hari sebanyak 2 kali

6) Porsi makan MP ASI usia 6 bulan 2 minggu -8 bulan 29 hari adalah 1 mangkuk ukuran $250 \mathrm{ml}$

7) Ajak anak makan sambil menonton televisi agar anak mau makan

8) Batasi waktu pemberian makan maksimal 30 menit meskipun makanan belum habis

9) Hindari bahan makanan beku

10)Menambahkan gula pada makanan anak dapat menyebabkan anak kelebihan gula sehingga anak berisiko terkena penyakit gula

Materi mengenai pengetahuan awal pemberian MP-ASI ini penting dilakukan untuk peningkatan pengetahuan warga tentang gizi balita.

\section{B. Menu MP ASI Pedoman Gizi Seimbang}

Pengabdian masyarakat ini bertujuan untuk mengendalikan faktor risiko masalah gizi balita yang ada di Dusun Gumulan maka dari itu penting untuk menyampaikan materi penyuluhan mengenai pedoman gizi seimbang dalam pemberian MP ASI agar memenuhi kebutuhan tumbuh kembang anak. Ada 10 pertanyaan yang diberikan kepada warga mengenai pedoman gizi seimbang diantaranya adalah:

1) Menu makan yang baik adalah menu 4 sehat 5 sempurna

2) Menu gizi seimbang beranekaragam terdiri dari makanan pokok, lauk pauk, sayur dan buah-buahan 
3) Telur ayam tidak boleh diberikan sebagai bahan makanan mp asi pada anak kurang dari 12 bulan

4) Jagung termasuk jenis bahan makanan pokok

5) Tahu dan Tempe termasuk jenis makanan dengan bahan dasar kacang-kacangan

6) Susu termasuk jenis sumber makanan hewani

7) Mentega termasuk jenis minyak dan lemak

8) Susu wajib diberikan kepada anak mulai usia $\geq$ 6 bulan

9) Kualitas buah impor lebih bagus dibanding buah lokal

10)Minyak dan lemak diberikan 1 sendok makan per hari

Materi mengenai pedoman gizi seimbang ini diberikan agar masyarakat mengalami peningkatan partisipasi aktif, pengetahuan, dan keterampilan warga dalam memanfaatkan hasil alam untuk mengolah berbagai varian MP-ASI menggunakan bahan pangan lokal berkualitas.

\section{Hypnoeating}

Hypnoeating adalah mendidik dengan memasukkan sugesti positif nagar anak memiliki perilaku dan kebiasaan konsumsi pangan yang baik. Sikap dan perilaku anak merupakan hasil dari rangsangan stimulus yang berupa perkataan dan tindakan dari orang tua dan lingkungannya, maka dari itu penting untuk mengetahui teknik hypnoeating pada unak agar terbentuk kebiasaan makan dengan teladan dan sikap positif. Ada 10 pertanyaan yang meliputi materi hypnoeating:

1) Teknik hypnoeating dilakukan saat anak dalam kondisi santai

2) Saat anak dalam kondisi mengantuk, anak sulit menerima saran-saran positif

3) Mengucapkan kalimat-kalimat positif saat melakukan teknik hypnoeating pada anak dalam keadaan santai dapat terekam dan tersimpan dengan baik di otak anak

4) Teknik hypnoeating dilakukan minimal 30 kali berturut turut

5) Saat anak tidak mau mengunyah makan, katakan "makan nya yang cepat, jangan di emut"

6) Katakan "Waktunya makan, ayo duduk" setiap kali akan makan agar anak memiliki kebiasaan makan yang baik

7) Hpnosis tanpa relaksasi dilakukan saat anak dalam kondisi tenang
8) Saat melakukan hypnosis tanpa relaksasi, mata Ibu dan mata anak saling memandang

9) Hypnosis dengan relaksasi dilakukan saat menjelang tidur

10) Mmmm sayur enak, buah enak, semua enak dan sehaatt " merupakan salah satu kalimat positif yang dapat dikatakan dalam teknik hypnoeating

Materi ini disampaikan agar warga dapat mengetahui hal apa saja yang harus dilakukan untuk menerapkan Peningkatan partisipasi aktif, pengetahuan, dan keterampilan warga dalam menerapkan teknik hypnoeating pada anak.

Hasil pembahasan ketiga materi tersebut dapat dilihat pada grafik perbandingan tingkat pengetahuan sebelum dan sesudah dilakukannya intervensi.

Grafik I. Tingkat Pengetahuan Warga Sebelum Intervensi

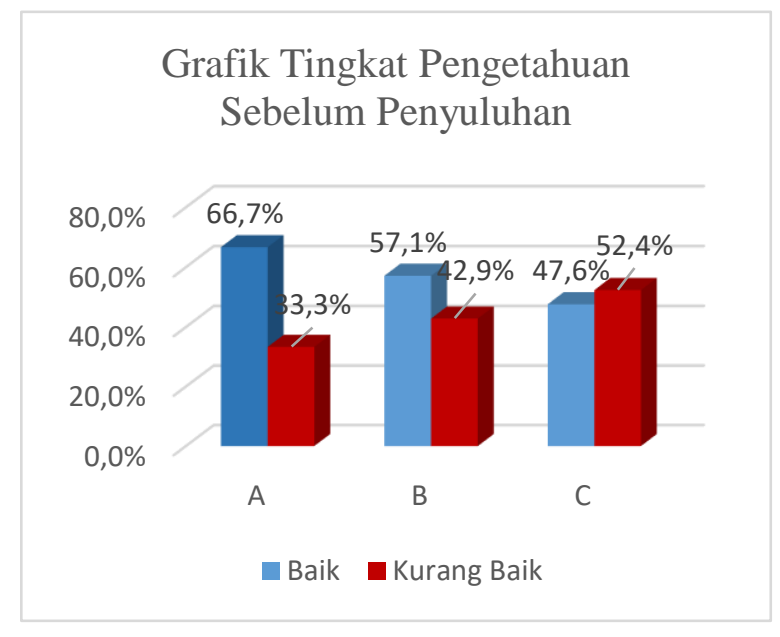

Berdasarkan grafik 1, dapat kita ketahui bahwa sebesar $66,7 \%$ warga masyarakat menjawab baik materi A tentang pengetahuan awal MP-ASI dan sekitar 33,3\% warga menjawab kurang baik sebelum dilakukan penyuluhan. Pada materi $\mathrm{B}$ atau Pedoman gizi seimbang sebanyak $57,1 \%$ warga menjawab pertanyaan dengan baik dan $42,9 \%$ menjawab tidak baik, begitu pula dengan materi $\mathrm{C}$ atau pengetahuan tentang Hypnoeating 47,6\% warga masyarakat menjawab pertanyaan dengan baik dan sebanyak $52,4 \%$ warga masyarakat menjawab pertanyaan dengan kategori kurang baik.

Berdasarkan jawaban warga tentang pengetahuan awal MP-ASI pada pertanyaan materi A soal nomor tiga "Tekstur MP ASI untuk anak usia 6 bulan -6 bulan 2 minggu adalah bubur kental", soal nomor empat "Tekstur MP ASI untuk anak usia $\geq 12$ bulan adalah 
cincang halus" sebagian besar warga masyarakat menjawab pertanyaan tersebut salah. Usia 6 bulan sampai dengan 24 bulan, merupakan masa rawan pertumbuhan bayi/anak. Pada periode ini merupakan proses dimulainya pemberian makanan khusus selain ASI, berbentuk padat atau semi padat secara bertahap jenis, jumlah, frekuensi, maupun tekstur dan konsistensinya sampai seluruh kebutuhan nutrisi anak dipenuhi. Memulai pemberian MP-ASI pada saat yang tepat sangat bermanfaat bagi pemenuhan kebutuhan nutrisi dan tumbuh kembang anak. Tumbuh kembang anak akan terganggu jika makanan pendamping tidak diperkenalkan pada usia 6 bulan, atau pemberiannya dengan cara yang tidak tepat.

Pada materi B tentang pedoman gizi seimbang berdasarkan hasil pada pertanyan no satu "Menu makan yang baik adalah menu 4 sehat 5 sempurna" dan pertanyaan empat "Telur ayam tidak boleh diberikan sebagai bahan makanan mp asi pada anak kurang dari 12 bulan" sebagian besar warga menjawab pertanyan tersebut dengan salah. Pedoman gizi seimbang untuk pemberian MP-ASI sangatlah mempengaruhi tumbuh kembang bayi. Dalam keadaan gizi yang baik, tubuh mempunyai cukup kemampuan untuk mempertahankan diri terhadap penyakit infeksi. Untuk menjamin agar kebutuhan nutrisi terpenuhi, MP-ASI harus selalu menggunakan pedoman gizi seimbang dengan menu empat bintang. Empat jenis kelompok makanan yang sebaiknya selalu tersedia dalam MP-ASI adalah makanan pokok atau nasi, lauk-pauk, kacang-kacangan, serta sayuran dan buah, kandungan nitrisi dalam jenis makanan ini lah berpengaruh terhadap tumbuh kembang bayi.

Pada materi $\mathrm{C}$ tentang hypnoeating menunjukkan hasil bahwa pada pertanyaan nomor dua, "Saat anak dalam kondisi mengantuk, anak sulit menerima saran-saran positif', dan pertanyaan nomor empat "Teknik hypnoeating dilakukan minimal 30 kali berturut turut" sebagian warga masyarakat dusun gumulan menjawab pertanyaan dengan jawaban yang salah. Ibu penting memberikan makanan dengan kesan baik untuk bayi karena perilaku yang baik akan membetuk kebiasaan makan anak dengan baik pula. Hypnoeating memiliki prinsip, bahwa semua yang dikatakan dan dilakukan secara terus menerus pada hakikatnya adalah suatu proses hipnosis karena akan terpola pada pikiran bawah sadar anak. Tehnik hypnoeating dilakukan pada saat anak berada pada gelombang pikiran Alpha dan Theta, karena pada saat anak ada dalam keadaan hipnosis seseorang secara selektif menjadi fokus, mengasyikkan dan berkonsentrasi (dengan relaksasi atau tanpa relaksasi/kondisi terjaga). Dalam keadaan hipnosis inilah, seorang anak mudah menerima saran-saran positif. Saran-saran positif tersebut akan terus tersimpan pada pikiran bawah sadar mereka, mengisi rekaman-rekaman dalam pikiran mereka tentang segala sesuatu yang bersifat positif yang berguna dalam mengisi sisi kejiwaan dan emosional mereka.

Grafik II. Tingkat Pengetahuan Warga Setelah Penyuluhan

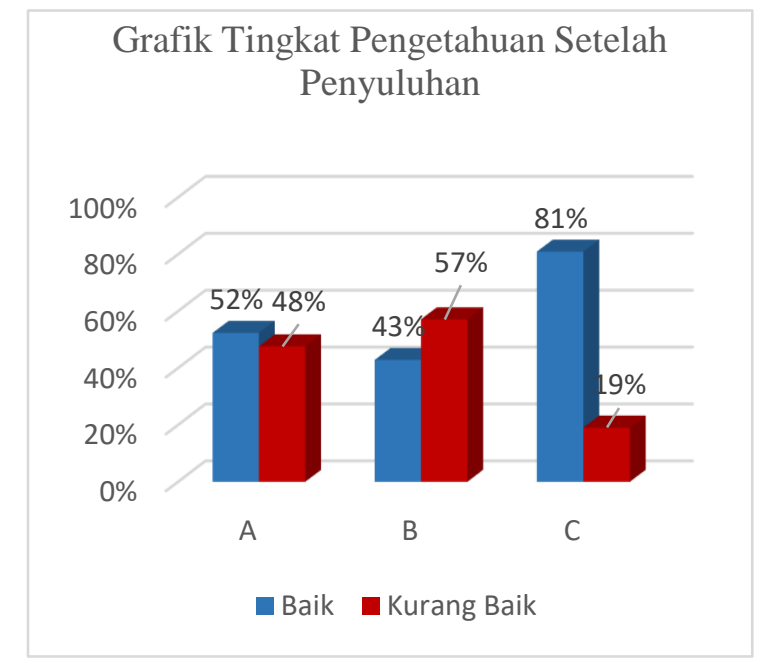

Berdasarkan grafik II dapat disimpulkan bahwa setelah dilakukan penyuluhan tingkat pengetahuan warga tentang materi A Pengetahuan awal MP-ASI) sebanyak $52 \%$ warga menjawab jawaban dengan kategori baik dan $48 \%$ mejawab dengan kategori kurang baik. Berdasarkan hasil jawaban warga pada materi A pada petanyaan nomor empat dan lima masih banyak warga menjawab pertanyaan dengan kategori kurang baik. Hal ini perlu di kaji lebih dalam lagi mengingat bahaya atau risiko yang terjadi pada bayi jika pemberian MP-ASI yang tidak tepat akan menyababkan bayi mengalami, kembung, tersedak saat diberi makanan, batuk dan rusaknya system pencernaan karena ginjal belum cukup berkembang untuk dapat menguraikan sisa yang dihasilkan oleh makanan padat.

Berdasarkan grafik II tingkat pengetahuan warga setelah dilakukan penyuluhan pada materi B (Pedoman Gizi Seimbang) sebanyak $43 \%$ menjawab dengan kategori baik dan $57 \%$ menjawab dengan kategori kurang baik. Pada pertanyaan nomor satu dan tiga setelah dilakukan penyuluhan masih banyak warga yang menjawab pertanyaan dengan salah. Oleh karena 
itu, hal ini perlu dikaji lebih dalam lagi untuk meningkatkan pengetahuan warga tentang pedoman gizi seimbang untuk MP-ASI. Karena pedoman gizi seimbang sangat lah penting untuk pertumbuhan dan perkembangan anak. Menu MP-ASI harus memenuhi 4 bintang yaitu; Karbohidrat, protein nabati, protein hewani serta buah dan sayur.

Berdasarkan grafik II. Pada materi C (Hypnoeating) sebesar $81 \%$ warga menjawab pertanyan dengan kategori baik dan $19 \%$ menjawab dengan kategori kurang baik. Jadi dapat dikatakan bahwa terdapat peningkatan pengetahuan warga setelah dilakukan penyuluhan terhadap materi hypnoeating.

Penyuluhan dalah suatu upaya atau kegiatan untuk menciptakan perilaku masyarakat yang kondusif untuk kesehatan. Penyuluhan tentang MP-ASI ini dilihat sebagai sistem, proses belajar dalam kegiatan menyangkut aspek masukan (input), proses dan keluaran (output). Masukan dalam penyuluhan tentang MP-ASI menyangkut sasaran belajar yaitu ibu-ibu yang berda Dusun Gumulan, Caturharjo, Pandak, Bantul.

Penyuluhan tentang praktek pemberian MP-ASI kepada ibu-ibu yang memiliki bayi 6-12 bulan dapat memperbaiki praktek pemberian MP-ASI. Penyuluhan adalah pendekatan edukatif yang menghasilkan perilaku masyarakat yang diperlukan dalam peningkatan gizi. Pada pengabdian ini penyuluhan menggunakan metode ceramah dan diskusi Tanya jawab serta mempraktikkan pembuatan MP-ASI.

Melakukan praktek pembuatan makanan pendamping asi (MP-ASI) kepada bayi, dengan harapan warga masyarakat dusun Gumulan khususnya ibu-ibu rumah tangga memahami materi yang diberikan serta memiliki keterampilan yang lebih baik dalam pemberian MP-ASI. Pengetahuan MP-ASI yang baik akan mempengaruhi atau mengubah praktek pemberian MP-ASI yang baik pula, begitu sebaliknya apabila pengetahuan yang kurang akan mempengaruhi praktek pemberian MPASI yang kurang juga ${ }^{3}$.

Materi pelatihan MP-ASI meliputi pemberian resep pembuatan makanan pendamping asi berdasarkan usia untuk anak umur 6-9 bulan, 9-12 bulan dan $>12$ bulan. Berikut adalah persentase tingkat pengetahuan warga sebelum dan sesudah dilakukan penyuluhan.

\section{KESIMPULAN}

Berdasarkan hasil evaluasi kegiatan pemberdayaan optimalisasi peran Ibu dalam pengendalian faktor risiko masalah gizi balita di Dusun Gumulan, Caturharjo, Bantul dapat disimpulkan bahwa warga dapat memahami dengan baik materi yang disampaikan dalam pelatihan. Warga berharap ada kegiatan serupa yang dilakukan secara berkelanjutan.

\section{UCAPAN TERIMA KASIH}

Terima kasih kami ucapkan kepada Kemenristek Dikti yang telah mendanai program PKM 2019.

\section{DAFTAR PUSTAKA}

[1] Badan Perencanaan Pembangunan Nasional. 2012. Pedoman Perencanaan Program Sadar Gizi dalam Rangka Seribu Hari Pertama Kehidupan (1000 HPK). Jakarta : Badan Perencanaan Pembangunan Nasional

[2] Kusumawati, Eri., Setiyowati Rahardjo, dan Hesti Permata Sari. 2015. Model of Stunting Risk Factor Control among Children under Three Years Old. Jurnal Kesehatan Masyarakat Nasional, Vol. 9. No. 3. Hal . 249-256.

[3] Yulianti J, 2010. Hubungan Antara Tingkat Pengetahuan Ibu Dan Praktek Pemberian MakananPendamping ASI Dengan Status Gizi Bayi Usia 6 Sampai 12 Bulan

[4] Badan Penelitian dan Pengembangan Kesehatan. 2010. Laporan Nasional Riset Kesehatan Dasar (Riskesdas) Tahun 2010. Jakarta : Kementerian Kesehatan Republik Indonesia.

[5] Kementerian Koordinator Bidang Kesejahteran Rakyat Republik Indonesia. 2013. Pedoman Perencanaan Program Gerakan 1000 Hari Pertama Kehidupan. Jakarta : Kementerian Koordinator Bidang Kesejahteran Rakyat Republik Indonesia.

[6] Sutarto, Diana Mayasari dan Reni Indriyani. 2018. Stunting, Faktor Risiko dan Pencegahannya. Jurnal Agromedicine, Vol. 5. No. 1. Hal 540-545.

[7] Kurniasih, Dwi Endah dan Joko Adianto. 2018. Kebun Gizi sebagai Strategi Berbasis Masyarakat Untuk Memenuhi Kebutuhan Konsumsi. Berita kedokteran Masyarakat (BKM Journal of Community Medicince and Public Health). Vol. 34. No. 2. Hal. 93-97.

[8] Saragih, Bernatal. 2010. Analisis Kebijakan Penanganan Masalah Gizi di Kalimantan Timur Berdasarkan Pengalaman Berbagai Negara. Jurnal Borneo, Vol. 6. No 3. Hal 1-20. 